\title{
Simo Mikkonen
}

\section{MUSIIKIN, POLITIIKAN JA IDEOLOGIAN RAJANKÄYNTIÄ}

\section{Neuvostomusiikin perestroika 1930 -Iuvun alussa}

Neuvostoliiton valtiollisen kehityksen kannalta 1930-lukua on pidetty ratkaisevana käännekohtana. Kommunistisen puolueen pääsihteerin Iosif Stalinin lujittuva ote puolueen ja valtion johdossa aiheuttivat Neuvostoliiton muuttumisen totalitaarisesti hallituksi poliisivaltioksi. Stalinin hallinnon on katsottu huipentuneen toisen maailmansodan jälkeen, mutta myös 1930-luvusta mieleen ovat jääneet laajamittaiset vainot ja poliittinen terrori. Kylmän sodan jälkeinen neuvostohistorian tutkimus on kuitenkin kyseenalaistanut totalitaarisen hallintomallin. Nykyään ollaan yleisesti sitä mieltä, että vaikka Stalinin pyrkimys oli tehdä Neuvostoliitosta ehdottoman keskusjohtoisesti hallittu poliisivaltio, ei täydellistä totalitarismia koskaan syntynyt. Myös Stalinin yhteiskunnassa oli mahdollista toimia rajoituksista huolimatta.

Tarkastelen seuraavassa musiikin, Neuvostoliiton valtapolitiikan ja marxilais-leniniläisen ideologian keskinäistä vuorovaikutusta. Pureudun käsityksiin musiikista sen ideologisissa ja poliittisissa konteksteissa, ilman teosanalyysiä. Kirjoitukseni pohjaa neuvostosäveltäjien ja musiikkitieteilijöiden näkemyksiin musiikin luonteesta, sekä yleisesti tutkimuksiin taiteen asemasta Neuvostoliitossa. Lyhyesti sanottuna yritän selvittää lukijalle millainen asema musiikilla taiteena oli neuvostoyhteiskunnassa.

Neuvostoliittolainen yhteiskunta oli 1930-luvulla kaikkea muuta kuin vakaa ja sosialistinenkin se oli vain osittain. Stalinin pyrkimys maan ehdottomaksi johtajaksi näkyi selkeänä keskusjohdon vahvistumisena ja vallan keskittymisenä kommunistiselle puolueelle. Valtio pyrki puolueen johdolla virallisesti kohti sosialismia, vaikka useista sosialismin tunnusmerkeistä, kuten tasapalkkaisuudesta luovuttiinkin. Useat 1930-luvun tapahtumat selittyvät juuri uuden yhteiskunnan rakentamispyrkimysten kautta. (Vihavainen 2000: 228; ks. myös Tucker 1998.) Puolue tunkeutui yhteiskunnan kaikkiin kerroksiin syrjäyttäen vielä 1920-luvulla merkittävässä asemassa olleet ammattiliitot sekä useat työväestön keskuudessa syntyneet neuvostot. Neuvostoliitto muodostui vähitellen 1930-luvun kuluessa ylhäältä käsin johdetuksi, kommunistisen puolueen harvainvallaksi, jonka ehdoton johtaja oli viime kädessä Stalin. (Volkogonov 1999: 185; Tucker 1998: 8-12.) Sosialismin korvasi totalitarismi. 


\section{Proletariaatin taidetta}

Tärkeä askel kohti keskusjohtoista, totalitarismiin pyrkivää vallankäyttöä otettiin vuonna 1928, ensimmäisen viisivuotissuunnitelman käynnistyttyä. Neuvostohistorioitsija Peter Kenez (1999: 80) on arvellut tämän olleen koko Neuvostoliiton historian merkittävin käännekohta, jonka seurauksena lopulta syntyi koko stalinistinen hallinto. Samanaikaisesti ensimmäisen viisivuotissuunnitelman kanssa alkoi myös kulttuurivallankumous, joka muutti huomattavasti vanhan älymystön, intelligentsijan, ja taiteilijoiden asemaa Neuvostoliitossa.

Vuoden 1917 vallankumoukset ja bolshevikkien valtaannousu eivät vielä suoraan muuttaneet taiteilijoiden asemaa, osa älymystöstä oli jopa bolshevikkien tukena. Suurelle osalle älymystöä olisi kuitenkin riittänyt ensimmäinen, helmikuun vallankumous ja itsevaltaisen monarkian kaatuminen. Marxin oppeja tulkitseville bolshevikeille taide ei ollut ensisijainen ongelma uudessa valtiossa. Marxilais-leninismin tärkeimmät elementit liittyivät talouteen ja poliittiseen kontrolliin. Marxilaisen analyysin mukaan taide oli aina palvellut jonkin luokan tarpeita. Taide oli 1800-luvulla tyydyttänyt ennen kaikkea porvariston tarpeita. Marxilaisittain taiteen arvo määräytyikin sen mukaan, kuinka se kykenisi palvelemaan proletariaatin tarpeita. Leninin pyrkimys älymystön osalta oli ensisijaisesti estää uuden yhteiskunnan mahdollinen horjuttaminen. (Perris 1985: 68-71; Kenez 1989: 361.) Ajatus siitä, että taide pitäisi valjastaa palvelemaan massojen tarpeita, nousi esille 1920-luvun kuluessa.

Uudessa valtiossa harjoitettu sensuurikaan ei ollut uusi asia. Kaikkialla maailmassa sensuurilla on aina estetty haitalliseksi katsotun taiteen tekeminen ja luotu näin tabuja, asioita joiden kuvaaminen on kielletty. Myös Venäjän keisarikunnassa sensuuri oli taiteilijoille tuttua. Sensuuri, tiettyjen asioiden kieltäminen ei vielä tee yhteiskunnasta totalitaarista. Totalitaariseksi se muuttuu siinä vaiheessa kun asioiden kieltämisen sijasta sanotaan mitä tulee esittää. Vasta virallisten, ehdottomien doktriinien asettaminen tekee taiteesta totalitaarisesti hallittua. (Esim. Perris 1985: 68.) Tämä ei ollut tilanne vielä 1920-luvulla. Kulttuurivallankumouksen (1928-31) aikana useat tahot pyrkivät antamaan taiteelle ehdottomat rajat, ja onkin väitetty, että sosialistisen realismin myötä näin olisi Stalinin Neuvostoliitossa 1930-luvulla käynyt. Yleisesti ottaen Stalinin näkökulmasta taiteet olivat vain väline, jolla vaikuttaa suoraan massoihin. Tässä mielessä taiteilijat pyrittiinkin valjastamaan osaksi valtiojärjestelmää.

Suurimmat muutokset valtion ja taiteen keskinäisissä suhteissa osuvat juuri 1930luvulle sekä 1920- ja 1930-lukujen taitteeseen. Taiteiden kannalta merkittäväksi noussut kulttuurivallankumous merkitsi huomattavaa välirikkoa vanhan venäläisen älymystön ja valtaa pitävien kommunistien välillä. Sheila Fitzpatrickin (1992: 91-114) klassisen, vuonna 1974 tekemän tulkinnan mukaan sisällissodan päättymisestä 1922 aina vuoteen 1927 kansankomissaari Anatoli Lunatsharskin ${ }^{1}$ johtamalla koulutus- ja taidesektorilla noudatettiin kulttuuripolitiikkaa, joka hyväksyi puolueen ulkopuolisen 
vanhan älymystön melko vapaan toiminnan. Kuitenkin jo ennen kulttuurivallankumousta oli useita tahoja, jotka pyrkivät eroon vanhasta älymystöstä ja keisarillisen Venäjän aikaisista porvarillisista taiteilijoista. Kulttuurivallankumouksen aikana nämä pyrkimykset pääsivät purkautumaan. (Fitzpatrick 1992: 115-116.) Kulttuurivallankumous nimitys on käsitteenä pyritty myös kyseenalaistamaan (esim. David-Fox 1999), joskin tapahtumien kulusta ollaan yhtä mieltä.

Kulttuurivallankumous oli marxilais-leniniläisen ideologian käsite. Viimeisinä elinvuosinaan Lenin keskitti suuren osan energiastaan ratkaistakseen Venäjän takapajuisuuden ongelman - kuinka Venäjä olisi mahdollista nykyaikaistaa ja tuoda länsimaiden tasolle. Vain näin proletariaatti lunastaa paikkansa uudessa valtiossa. Tästä syystä Lenin asetti koulutustason radikaalin nostamisen merkittävään asemaan. (Esim. Fitzpatrick 1992: 116; Kenez 1989: 360-361.) Leninin käsitys kulttuurista yleensä oli hyvin läheisesti kytköksissä neuvostovallan tukemiseen. Sivistynyt ihminen ja neuvostovaltion toimia tukenut ihminen olivat näin lähekkäisiä asioita. Niinpä valtion kulttuuri-, koulutus- ja taideasioista huolehtiva valistusasiain kansankomissariaatti, Narkompros, piti sisällään myös poliittisen kasvatuksen laitoksen. (Kenez 1989: 363.)

Osa bolshevikkien (myöh. kommunistien) pyrkimyksistä kulttuurivallankumoukseksi kutsuttuna ajankohtana selittyykin Leninin kulttuurikäsityksellä - samaan aikaan kun puolueen jäsenten ja työläisten kulttuuritasoa pyrittiin nostamaan radikaalisti, myös eri ammattiryhmiä pyrittiin muuntamaan puoluemielisiksi. Luokkasodan käsite nousikin vahvasti esille. Tämä näkyi erityisesti nuorten kommunistien pyrkimyksissä purkaa byrokratioita. Esimerkiksi yliopistoihin vaadittiin proletaarista johtoa. Tämä pyrkimys nousi ennen kaikkea nuorten ja eri ammattiryhmien kommunistien, eikä suinkaan puoluejohdon, piiristä. (Fitzpatrick 1992: 125, 136.) Tämä tavoite vaikutti myös musiikillisiin instituutioihin, joiden johto oli pitkälti porvarillistä syntyperää (ks. Schwarz 1983: 101-102). Osalle taiteilijoista kulttuurivallankumous loi uusia mahdollisuuksia, mutta erityisesti nimekkäät taiteilijat joutuivat ahtaalle.

Ennen kulttuurivallankumousta 1920-luvun Euroopassa oli tähyilty Neuvostoliittoon taiteiden luvattuna maana. Moni eurooppalainen taiteilija oli kadehtinut valtion varsin avokätistä tukea neuvostotaiteelle. Erityisesti moderni taide kukoisti ja sai toteuttaa itseään. Leningrad toimi yhtenä merkittävistä modernin taiteen keskuksista Euroopassa. Moderneja huippusäveltäjiä, jotka 1920-luvun sallivassa ilmapiirissä joko vierailivat tai joiden musiikkia esitettiin Neuvostoliitossa, edustavat Stravinski, Berg, Honegger, Schönberg ja Hindemith. (Brooke 2001: 234; Schwarz 1983: 62-63.) Kulttuurivallankumouksen myötä modernistit joutuivat kuitenkin ahtaalle ja yhteydet muualle Eurooppaan tyrehtyivät väliaikaisesti (Kenez 1999: 101-102).

Kulttuurivallankumouksen kommunisteja innostaneessa, mutta toisaalta perinteitä repineessä ilmapiirissä havaittiin pian, että proletariaatin itsensä spontaanisti luoma 
taide on käytännössä mahdottomuus. Kulttuurivallankumouksen kantava ajatus oli ollut vanhan, porvariston luoman kulttuurin ja taiteen korvaaminen proletariaatin omaehtoisesti luomalla kulttuurilla. Kulttuurivallankumouksen päätyttyä 1931 näytti siltä, että kaikkialla Neuvostoliitossa tapahtui paluuta perinteisiin arvoihin. Armeijassa palautettiin upseerinarvot, kouluihin palautettiin kuri, sekä opettajan auktoriteetti ja sukupuolista vapaamielisyyttä purettiin. Myös taiteissa pyrittiin ylhäältä käsin palauttamaan perinteinen taide arvoonsa. (Vihavainen 2000: 231-233.)

\section{Taiteen ja musiikin perestroika}

Taidemaailman 1930-luvun alun tapahtumia voidaan kutsua taiteiden perestroikan, uudelleenjärjestelyn, ajaksi. Termi ei kuitenkaan ole vakiintunut käsite. Perestroika oli ennen kaikkea puolueen taidepoliittisesta toiminnastaan käyttämä käsite. Musiikkitieteilijät Richard Taruskin (1997: 511) ja Stanley Krebs (1970: 51-52) ovat molemmat korostaneet puolueen roolia taideliittojen perustamisessa. Heidän mukaansa taiteiden uudelleenjärjestelyssä oli kyse Stalinin halusta osoittaa taiteille näiden paikka yhteiskunnassa. Tämä kuvastaa hyvin Stalinin ja puolueen pyrkimyksiä sitoa taiteet keskitetyn hallinnon osaksi. Venäjän kulttuurihistoriaan laajasti perehtynyt Pekka Pesonen (1998: 173) on tiivistänyt asian siten, että 1930-luvun alussa kirjavat ryhmittymät muuttuivat puolue- ja valtiojohtoisiksi taideliitoiksi, jotka saivat lopullisen vallan taide-elämässä. Kullekin taiteen alalle luotiin oma liittonsa. On kuitenkin huomattava, että taideliitot myös edistivät monin tavoin jäsentensä oloja ja toimivat oman alansa keskustelu- ja kehitysfoorumina. Niiden tarjoama hyvinvointi oli kansainvälisesti katsottuna poikkeuksellisen hyvä, mutta myös rajoitukset poikkeuksellisen ankaria. (Krebs 1970: 51; Pesonen 1998: 173; Hingley 1979: 197.)

Taiteilijoita on usein pidetty uhreina viitattaessa taideliittojen ja sosialistisen realismin syntyyn. Stalinin toimia ja terroria tarkasteltaessa koko neuvostokansa oli toki uhrin asemassa. Tällöin kuitenkin unohdetaan taiteilijoiden oma rooli uudistuksissa. Taiteilijat hyväksyttiin taideliittojen perustamisella osaksi uutta neuvostoeliittiä. Stalinin kaudella älymystö, intelligentsija, sai uuden merkityksen. Se tuli merkitsemään uutta hallitsevaa luokkaa, koko virkamiehistöä, jolla oli huomattavasti tavallista kansaa paremmat elinolosuhteet (Fitzpatrick 1992: 218-219). Nyt myös taiteilijat pääsivät virallisesti nauttimaan näistä etuisuuksista. Taideliittojen materiaalinen hyöty olikin ilmeinen.

Taideliittojen kautta syntyneet rajoitukset ovat tiivistyneet sosialistisen realismin käsitteeseen. Koko kylmän sodan aikaisessa tutkimuksessa vallitsi jähmettynyt näkemys tämän käsitteen luonteesta. Neuvostoliitossa tehdyssä tutkimuksessa korostettiin, että sosialistinen realismi oli ohjaava, taiteilijaa sitomaton periaate. Länsimainen tut- 
kimus taas on korostanut sosialistista realismia taiteen totalitaarisen hallinnon peruspilarina. Näin tarkasteltuna sosialistisesta realismista muotoutui suoranainen antiteesi taiteelliselle vapaudelle, jota 1900-luvun individualismia korostava taide-estetiikka pitää taiteellisen ilmaisun perustana (Groys 1992: 7). Selvää silti on, että sosialistinen realismi oli 1930-luvun puolivälin jälkeen neuvostotaiteen peruskäsitteitä.

Vanhojen taideyhdistysten lakkauttaminen ja yksittäisten taideliittojen perustaminen kullekin taiteelle alkoi vuonna 1932. Puolueen keskuskomitea antoi 23. huhtikuuta päätöslauselman Kirjallisten ja taiteellisten organisaatioiden uudelleenjärjestämisestä (Postanovlenie TsK VKP(b) 23.4.1932). Päätöslauselmassa todettiin kulttuurivallankumouksessa tärkeää osaa esittäneiden proletaaritaiteilijoiden yhdistysten lakkauttaminen, sekä taidekohtaisten liittojen perustaminen kaikille neuvostovaltiota tukeville taiteilijoille. Taideliittoihin pääsyn edellytyksenä ei ollut puolueen jäsenkirja vaan taiteen harjoittaminen (Schwarz 1983: 110; vrt. Korzhihina 1990). Käytännössä päätöslauselman seurauksena jäljelle jäi vain valtioon sidoksissa oleva taidesektori - taide valtiollistui.

Säveltäjien keskuudessa päätöslauselma tulkittiin sävyltään selkeästi positiivisena. Päätöslauselman seurauksena sekä Leningradiin että Moskovaan perustettiin jo elokuussa 1932 jaostot tulevalle säveltäjäliitolle. Tammikuussa 1933 ilmestyi myös Sovetskaja Muzyka ("Neuvostomusiikki") -lehden ensimmäinen numero. Lehti julkaisi paitsi tieteellisiä artikkeleita musiikista, myös säveltäjien ja musiikkitieteilijöiden kirjoituksia omasta työstään sekä näkemyksiä musiikin luonteesta. Ensimmäisissä numeroissa nouseekin esille, kuinka puolueen päätös lakkauttaa proletaarimuusikoiden yhdistys ja perustaa taideliitot otettiin tervetulleena vastaan. Muun muassa säveltäjä Nikolai Rimski-Korsakovin poika Andrei Rimski-Korsakov (1933: 126) katsoi, että päätöslauselman jälkeen tutkimustyölle oli jälleen paremmat edellytykset. Hän viittaa proletaarimuusikoiden yhdistyksen toimiin, jotka vaikeuttivat hänen pääsyään arkistoihin.

Sovetskaja Muzykassa korostettiin pääkirjoituksia myöten toverillisen yhteistyön merkitystä uudessa liitossa. Säveltäjien keskinäisten riitojen ajan tuli olla nyt takanapäin. (Sovetskaja Muzyka 5/1934: 5.) Myös useat musiikin ammattilaiset korostivat ilmapiirin parantumista. Neuvosto-oopperan merkittävänä kehittäjänä pidetty Andrei Pashtshenko (1933: 122) kirjoitti musiikkimaailmaa vaivanneesta kuppikuntaisuudesta, venäjäksi gruppovshtshina. Hän katsoi ilmiön juurtuneen syvälle säveltäjäyhteisöön ja vahingoittavan neuvostomusiikin normaalia kasvua. Hän viittasi proletaarimuusikoiden yhdistyksen ja modernistisen ASMin vanhoihin kiistoihin, joiden hän katsoi vaikuttaneen haitallisesti eri musiikillisten instituutioiden toimintaan.

Kulttuurivallankumouksen vuodet olivat olleet proletaarimuusikoiden yhdistykselle, RAPMille, sen ehdoton valtakausi. RAPMin toimintaa vuosina 1929-31 on yleensä kuvattu militantiksi ja autoritaariseksi. Parhaiten heidän toimistaan muistetaan 
modernin musiikin vastainen toiminta. (Esim. Schwarz 1983: 57-59; vrt. Nelson 2001: 101.) Proletaarimuusikoiden yhdistyksen valtakausi vaikuttaa varsin lyhyeltä, mutta näyttäisi siltä, että heidän vaikutuksensa jatkui osaltaan myös tulevassa säveltäjäliitossa.

Kulttuurivallankumouksen vuosina RAPM keskittyi "musiikkiin massoille". RAPM kannusti säveltäjiä tekemään marssityyppisiä joukkolauluja, massovaja pesnja, agitprop-teksteihin ja vallankumousrunoihin. RAPM pyrki korvaamaan konservatorioiden vanhoja professoreita omilla ehdokkaillaan saavuttaen niissä määräysvallan. Myös musiikin osalta tapahtui siis pakkodemokratisointia. (Schwarz 1983: 102; Taruskin 1997: 93.) Tunnetuin esimerkki RAPMiin liittyneestä sävellystoiminnasta lienee Moskovalaisten opiskelijoiden kehittämä prokoll (proizvodstvennyj kollektiv, eli tuotantokollektiivi), säveltäjäyhteisö, joka kirjoitti vallankumousoopperoita ja -oratorioita kollektiivisesti. Käytännössä nämä teokset olivat joukkolaulukokoelmia. (Taruskin 1997: 512; Nelson 2001: 106.) Laadultaan nämä teokset eivät aina olleet erinomaisia. Sovetskaja Muzykassa nostettiin esille, että vuoden 1932 aikana proletaarisäveltäjien, kuten Belyj'n, Davidenkon ja Shehterin keskeisiä teoksia esitettiin radiossa usein, jopa 3-4 kertaa päivässä. Tämä oli aiheuttanut radiokuuntelijoiden protestiaallon. (Groman-Solovtsov \& Ryzhkin 1933: 69.)

Vaikka puolue lakkauttikin proletaarimuusikoiden yhdistyksen päätöslauselmallaan 23.4.1932, ei RAPMin voimahahmojen ura päättynyt tähän. Pitkän uran tekivät esimerkiksi Juri Keldysh, joka muistetaan erityisesti massiivisen Neuvostomusiikin ensyklopedian toimittamisesta, sekä säveltäjä Lev Lebedinski, joka muun muassa auttoi Shostakovitshia toimittamaan Mtsenskin kihlakunnan Lady Macbeth -oopperasta Katerina Izmailova nimellä tunnetun uuden version. Toisin kuin on esitetty, RAPMin jäsenet toimivat aktiivisesti myös uudessa säveltäjäliitossa. Kattavan kuvauksen RAPMin toiminnasta on artikkelissaan tehnyt Amy Nelson (2001)2.

RAPMin korostama näkemys taiteen suuntaamisesta proletariaatille ei sekään kuollut yhdistyksen mukana. RAPM oli korostanut modenin musiikin haitallisuutta, koska sitä oli vaikea ymmärtää. Musiikki tulisi suunnata mahdollisimman laajalle kuulijakunnalle ja samalla tukea näiden kulttuurista kasvattamista. Tämän humaanin ajatuksen RAPMin toiminnassa kuitenkin turmeli pyrkimys määrittää oikea ja väärä. Historiallisista säveltäjistä yhdistys hyväksyi esimerkillisiksi lähinnä Ranskan vallankumousta kerran ihannoineen Beethovenin ja tsaarivaltaa arvostelleen Musorgskin. Käytännössä kaikki muut säveltäjät joutivat historian romukoppaan. Sovetskaja Muzykan päätoimittaja Nikolai Tsheljapov (1933b: 4) otti RAPMin toiminnan rajoittuneisuuden aiheeksi ensimmäisessä pääkirjoituksessaan. Hän korosti, että tämä RAPMin toiminnan rajoittuneisuus esti sen, ettei yhdistyksen toimintaa voinut käyttää pohjana uuden säveltäjäliiton toiminnalle. Työ tuli alkaa puhtaalta pöydältä. Myös RAPMin toiminta oman aikansa säveltäjiä ja musiikkitieteilijöitä vastaan sai huomattavaa 
kritiikkiä. Musiikkitieteilijä Ginzburg korosti (1934: 4) että RAPMin skemaattiset ohjeet olivat haitanneet huomattavasti musiikkitieteen kehitystä. Myös yhdistyksen tapa arvostella sävellykset vain joko hyviksi tai huonoiksi, oli haitallinen.

Proletaarimuusikoiden toiminnan kritisoimisesta huolimatta tunnettu musiikkitieteilijä David Rabinovitsh (Kaltat \& Rabinovitsh 1933a: 5-6) nosti esille sen, että ennen taideliittojen perustamista RAPM edusti sosialistista rakentamista musiikissa. Kirjoituksessa korostettiin huhtikuun päätöslauselman roolia jatkumona aiemmalle politiikalle. Kirjoituksen mukaan puolue oli pyrkinyt korjaamaan RAPMin tekemät erehdykset, mutta tarkoitus ei ollut luopua proletaarikulttuurin rakentamisesta. Sosialismin rakentaminen siirtyi taideliittojen perustamisen myötä vain uuteen vaiheeseen. Näyttäisikin todella siltä, että monet RAPMin painottamat asiat jäivät elämään uudessa säveltäjäliitossa, joskaan eivät välttämättä hallitsevina piirteinä. Sekä Moskovan että Leningradin säveltäjäliiton osastojen alkuvuosien toiminnan raporteissa nousee esille työ harrastajamuusikoiden parissa. Tehtaille ja kolhooseille ympäri Neuvostoliittoa perustettiin muusikkopiirejä, jopa orkestereita, joihin säveltäjäliitto antoi asiantuntija-apua. Myös sävellystyön suuntaamista harrastajille korostettiin. (Esim. Gorodinski 1933c: 2; Hubov 1934: 3; Sovetskaja Muzyka 3/1934: 77.)

Gorodinski (1933c: 2) esitti, että toiminta kansan ja työväestön parissa olisi tukena teoreettiselle ja tutkimuksen kautta tehdylle pohdinnalle musiikin sosialistista realismia kehitettäessä. Taide pitäisi hänen mukaansa viedä ulos sen perinteisistä esityspaikoista, konserttisaleista, sinne, missä tehtiin työtä: tehtaille, työpajoihin ja kolhooseille. Taidehistorioitsija Boris Groys (1992: 7) on esittänyt mielenkiintoisen käsityksen sosialistisesta realismista. Hän muistuttaa, että usein ihaillun 1920-luvun neuvostoavantgarden tärkeimpiä tavoitteita oli vielä taide ulos taidehalleista ja museoista. Tätä periaatetta toteutettiin 1930-luvulla varsin ahkerasti. Taidetta tuotiin myös esille erilaisten massatapahtumien yhteydessä ja joukkojen välityksellä. Esimerkiksi Moskovan metron taide säväyttää nykyäänkin. Gorodinskin jo varhain esittämä ajatus musiikin viemisestä kansan pariin edustikin eräänlaista siltaa proletaarimuusikoiden edustaman periaatteen ja tulevan sosialistisen realismin välillä.

Yleensä sosialistisen realismin käsite on liitetty kirjailijaliiton perustamiseen ja kirjailija Maksim Gorkiin. Yleisliittolaisen, kansallisen tason kirjailijaliiton perustamiskongressi pidettiin elokuun lopussa 1934. Kongressin yhteydessä esiteltiin määrittely myös sosialistiselle realismille. Tärkeitä puheenvuoroja pidettiin lukuisia, niin kirjailijoiden kuin puolueen edustajien toimesta. Kuva sosialistisesta realismista ei näiden puheiden perusteella ollut mitenkään sulkeutunut. Useissa pidetyistä puheista päinvastoin jopa korostettiin sosialistista realismia periaatteena, joka ei pakottaisi taiteilijaa mihinkään. (Esim. Stetsky 1977: 263.) Kirjailijaliitto todella perustettiin 1934 ja sosialistisesta realismista tuli sen ohjaava periaate. Sosialistisen realismin määrittely jäi kuitenkin siinä määrin avoimeksi, että tulkinnanvaraa oli sekä hyvässä että pahassa. 
Taiteilija saattoi hyödyntää sen avointa määrittelyä, mutta myös syytöksiä siitä, ettei taiteilija seurannut sosialistista realismia, oli varsin helppo nostaa.

Sosialistisen realismin myötä taiteen päämääräksi tuli kehittää sosialistista taidetta, sosialistisen yhteiskunnan taidetta. Taiteen kielen tuli olla yksinkertaista ja ymmärrettävää, moderneista ja avantgardistisista kokeiluista tuli ei-toivottuja. Sankaruus, optimistisuus ja sosialistisen yhteiskunnan rakentaminen tulivat virallisesti taiteen keskeisiksi päämääriksi. (McCauley 1981: 88; Hingley 1979: 199; Pesonen 1998: 173-175.) Yleensä on esitetty, että kirjailijaliiton ohella myös muille taiteille perustettiin omat taideliitot puolueen huhtikuun 1932 päätöslauselman myötä (esim. Garrard 1990: 6; Pesonen 1998: 173). Tosin osa tutkijoista on myös huomioinut säveltäjäliiton keskusorganisaation toimineen aluksi varsin väljästi (Boris Schwarz 1983: 112).

Erikoista onkin, että kirjailijaliiton lisäksi muita taideliittoja ei juuri ole tutkittu. Kehitys näyttäisi nimittäin edenneen niin, että kirjailijaliiton kaltaista kansallista organisaatiota ei säveltäjille perustettu ennen vuotta 1948. Neuvostomusiikin sanakirjasta löytyy harvinainen maininta siitä, että säveltäjäliiton perustaminen tapahtui vuosina 1932-48. (Jakovlev 1981) Sosialistista realismia ei asetettu musiikille ohjaavaksi periaatteeksi valtiollisen säveltäjäliiton kautta koko 1930-luvulla. Tästä huolimatta esimerkiksi säveltäjät olivat jo ennen kirjailijakongressia ehtineet kehitellä musiikin sosialistisen realismin käsitettä yli puolentoista vuoden ajan³ .

Sosialistisesta realismista täytyy ottaa vielä huomioon se, ettei sitä koettu alun perin uhaksi luovalle taiteelle. Moni taiteilija todella uskoi, että taiteet olivat jonkin uuden kynnyksellä. Optimistinen tunnelma ympäröi taideliittojen perustamista. Liittojen luomista seurannut todellisuus osoittautui kuitenkin lopulta taiteilijoita kohtaan painostavaksi, kuten oli tilanne koko yhteiskunnassa. Saavutettuja etuja varjosti puolueen jatkuva läsnäolo ja valvonta. Stalinin kautena alkuun saatettu kehitys vaurioitti taiteita pahoin ja sai aikaan pysyviä ongelmia luovien taiteiden kehityksessä. (Taruskin 1997: 94-95.) Taideliitot sinänsä eivät olleet negatiivinen asia. Negatiivisiksi ne teki vasta Stalinin pyrkimys käyttää liittojen suomia mahdollisuuksia omiin tarkoituksiinsa.

Leonid Maksimenkov (1997) on osoittanut, että puolue keskittyi aluksi tietoisesti kirjallisuuden asioihin. Musiikkiin puututtiin vain vähän ennen vuotta 1936. Silloinkaan aika ei ollut kypsä säveltäjäliiton lopulliselle perustamiselle, vaan työ lykkääntyi sodan vuoksi aina vuoteen 1948. Tuolloin pidetyssä säveltäjäliiton perustamiskongressissa puolue toimi varsin aktiivisesti (ks. Maksimenkov 1993: Herrala 2003). Vuonna 1936 alkanut antiformalismikampanja muistetaan musiikissa erityisesti Shostakovitshia vastaan tehdyn hyökkäyksen ansiosta. Puolueen pää-äänenkannattajassa, Pravdassa julkaistiin 28.1.1936 artikkeli, joka herätti aikanaan laajalti keskustelua musiikkipiirien lisäksi muidenkin taiteiden keskuudessa. Artikkeli tyrmäsi Shostakovitshin jo vuonna 1934 ensiesityksensä saaneen oopperan Mtsenskin kihlakunnan Lady Macbeth. Artikkelissa ooppera katsottiin täysin sopimattomaksi esitettäväksi 
Neuvostoliitossa. Helmikuun 6. julkaistiin toinen artikkeli, jossa tyrmättiin saman säveltäjän baletti Kirkas puro. (Ks. Maksimenkov 1997.)

Pravdassa julkaistiin näiden kahden artikkelin vanavedessä useita artikkeleita helmi- ja maaliskuun aikana, joissa todettiin neuvostomusiikin heikko ideologinen tilanne. Antiformalismikampanjan seurauksena moni suosittu teos katosi Neuvostoliitossa vuosiksi. Koko tapahtumasarja vaikuttaa suunnitellulta operaatiolta, jossa taideliitot pyrittiin saamaan varpailleen ja samalla myös ohjaamaan taiteita haluttuun suuntaan. Tästä voidaan vetää se johtopäätös, että taideliitot eivät toimineet sisäisesti yhden ideologian ohjaamina, vaan tarvittiin ulkoapäin tuleva impulssi, jolla ne palautettiin ruotuun. Musiikin osalta antiformalismikampanja näyttäisi osoittavan, että sosialistisen realismin periaatetta ei musiikissa ollut tähän mennessä sovellettu. Kyse oli siitä, että tyhjentävää määrittelyä sosialistisesta realismista musiikissa ei kyetty tekemään. Yrityksiä oli runsaasti, kuten Sovetskaja Muzykan kirjoitukset osoittavat.

Kaikki tämä kertoo merkittävän asian Neuvostoliiton 1930-luvun suuresta taidepoliittisesta muutoksesta. Massojen ei odotettu enää tekevän proletariaatin taidetta itsenäisesti, vaan taiteilijoiden johdolla. Taiteilijat oli jälleen nostettu jalustalle. Taideliittojen muodostaminen synnytti taiteilijoille mahdollisesti ensin harhakuvitelman siitä, että liitot oli erotettu poliittisista tapahtumista. Olihan kulttuurivallankumouksen aikainen vanhan älymystön sorto päättynyt. Taiteilijoiden asema näytti periaatteessa riippumattomalta, taideliiton turvatessa asunnon ja palkan. Taideliittojen perustamisen jälkeen ilmapiiri taiteen tekemiselle parani huomattavasti ja tilanne näytti vakiintuneen. Tämän valossa vuoden 1936 antiformalismikampanja näyttäisi taiteilijoiden kurinpalautukselta, jota eri tutkijat ovat korostaneet eri lähtökohdista käsin (Krebs 1970: 52; Perris 1985: 78; Fitzpatrick 1992: 214). Taiteilijat olivat toimineet 23.4.1932 annetun päätöslauselman jälkeen mahdollisesti liian itsenäisesti.

Antiformalismikampanjan aikoihin poliittinen terrori oli kiihtymässä ja laajeni puolueen ulkopuolelle. Säveltäjät kuitenkin joutuivat kärsimään suhteellisesti varsin vähän. Esimerkiksi Shostakovitshin maine palautettiin viidennen sinfonian myötä vuoden 1937 aikana, eikä häntä koskaan edes vangittu. Pravdan sivuilla useat eri sosialistiset sankarit totesivat Shostakovitshin kasvaneen taiteilijana ja saavuttaneen kansan vaatiman tason. Virallisesti hänen katsottiin nyt tekevän sosialistisen realismin mukaista taidetta. (Taruskin 1997: 517; Hingley 1979: 198; ks. myös Mikkonen 2002.)

Mihin olisi tarvittu vuoden 1936 antiformalismikampanjaa, jos säveltäjäliitto olisi ollut kirjailijaliiton kaltainen, sosialistisen realismin kontrolloima stalinistinen organisaatio? Musiikin käyttöä propagandavälineenä tutkineen Arnold Perrisin (1985: 81) mukaan säveltäjäliitolle muokattiin uusi politiikka vuonna 1957, toisen säveltäjäkongressin yhteydessä. Tarkoitus oli tuolloin puhdistaa säveltäjäliitto stalinismista. Perrisin oletuksena siis oli, että säveltäjäliitto oli vuonna 1957 stalinistinen organisaatio. Perris 
näyttäisi uskovan, että säveltäjäliitto oli ollut sitä perustamisestaan alkaen. Vastakkaiseen näkemykseen on päätynyt tutkija Caroline Brooke (2001: 231), joka katsoi, ettei puolueella ollut selkeää musiikkipolitiikkaa vielä 1930-luvulla.

Säveltäjäliiton ensimmäinen, 1948 pidetty kongressi liittyi toisen maailmansodan jälkeiseen kurinpalautukseen taiteissa. Sota-aikana useille tahoille oli sallittu vapauksia, jotka Stalin halusi jälleen poistaa sodan päätyttyä. Ensimmäisenä kohteena oli jälleen kirjallisuus, mm. kirjailijat Zoshenko ja Ahmatova. Musiikin osalta kurinpalautus oli uskottu Andrei Zhdanoville. Säveltäjäliiton 1946 alkanut puhdistus huipentui 1948 pidettyyn säveltäjäkongressiin. Hyökkäyksen huipensi tälläkin kertaa ooppera, Vano Muradelin Suuri ystävyys. (Esim. Herrala 2003.) Suurimman hyökkäyksen kohteeksi joutuivat kuitenkin Neuvostoliiton kuuluisimmat säveltäjät Prokofjev, Shostakovitsh, Miaskovski, Shebalin, Popov ja musiikkitieteilijät Asafjev, Livanova, sekä Gruber. Myös Hatshaturjan ja Kabalevski päätyivät mustalle listalle. (Krebs 1970: 56; Maksimenkov 1993: 8-9.) Tapahtumat noudattivat vuoden 1936 linjaa, mutta tällä kertaa totaalisesti - säveltäjä säveltäjältä ja teos teokselta osoitettiin mikä oli oikein, mikä väärin. Kosmopolitismi, formalismi, kansanvihollinen ja vastavallankumouksellinen olivat sanastoa, jolla säveltäjiä vastaan hyökättiin. Hindemith, Bartok, Honegger ja Schönberg nostettiin esimerkeiksi länsimaisen musiikin rappiotilasta. (Krebs 1970: 57.)

Taidemaailman laajamittainen painostus, jonka osia vuosien 1936-38 ja 1946-48 antiformalismikampanjat olivat, johtui Stalinin uskosta taiteiden propagandistiseen ja massoja liikuttavaan voimaan. Taiteet tuli yhtä kaikki saattaa stalinistisen yhteiskuntajärjestyksen piiriin. Stalinille kaikenlaiset vapaudet, kuten taiteellinen vapaus olivat vain esteitä hänen omien pyrkimystensä saavuttamisessa. (Volkogonov 1999: 132.) Stalinin pyrkimykset ja tulevat painostustoimet olivat kuitenkin vielä tuntemattomia säveltäjäyhteisölle ennen vuotta 1936. Onkin tärkeää huomata se, että vuoden 1936 antiformalismikampanja tehtiin nimenomaan kommunistisen puolueen äänenkannattajan, Pravdan, eikä valtiollisten taideliittojen kautta. Aiempi tutkimus on väittänyt taideliittojen olleen vain välineitä, joilla puolue kontrolloi taidetta. Tällöin antiformalismikampanjan merkitys ja taideliittojen perustamisvaihe jäävät osittain hämärän peittoon.

\section{Säveltäjäliitto järjestäytyy}

Taideliitto - tai luova liitto, tvortsheskij sojuz - otettiin säveltäjien keskuudessa vastaan positiivisena ilmiönä. Säveltäjät Leningradissa ja Moskovassa perustivat jaostot jo loppukesästä 1932. Näiden kautta säveltäjille ryhdyttiin järjestämään parempia olosuhteita, vakituista palkkaa, asuntoja, sekä työtiloja. Tämän toiminnan käynnistymisestä kertoo hyvin Sovetskaja Muzykassa (4/1933: 156-161) julkaistu artikkeli, 
jossa raportoitiin säveltäjien materiaalisen puolen kehittämisestä. Säveltäjäliitolle organisoitu pää-äänenkannattaja, Sovetskaja Muzyka taas takasi sen, että säveltäjillä oli oma foorumi, jossa musiikin tulevaisuudesta saattoi keskustella.

Taideliitoille oli kuitenkin selkeä ideologinen ja reaalipoliittinen perustelu myös puolueen näkökulmasta. Neuvostoliitto oli ideologinen valtio, joskin kyseenalaiseksi voidaan asettaa, mikä tämä ideologia oli. Virallisesti marxilais-leniniläinen ideologia oli kaikkia yhteiskunnan osa-alueita ohjaava periaate. Käytännössä Stalinin valtapoliittiset tavoitteet sysäsivät ideologiset tekijät toissijaisiksi. Tämä ei ollut kuitenkaan ilmeistä vielä 1930-luvun alkupuolella, jolloin marxilaisen ajattelun piirteitä nostettiin voimakkaasti esille myös musiikin piirissä. Kulttuurivallankumouksen ja antiformalismikampanjan väliin jäävällä neljän vuoden jaksolla säveltäjät omasivat suhteellisen paljon vapauksia ja saattoivat keskustella melko vapaasti siitä, minkälaista uuden sosialistisen taiteen tulisi olla. Näkemykset marxilaisuuden tuomisesta musiikkiin saivatkin varsin erilaisia hahmoja.

Neuvostomusiikin 1930-lukua käsittelevät teokset ovat olleet yleensä joko yleisesityksiä tai keskittyneet jonkun tietyn säveltäjän elämään. Säveltäjien yleiseen keskusteluun liittojen perustamisvaiheessa on viitattu vain harvoin. Keskustelusta nouseekin esille varsin mielenkiintoisia piirteitä. Säveltäjäliiton alkuvuosien toiminnassa ja käydyssä keskustelussa onkin mitä ilmeisimmin kyse politiikan, taiteen ja ideologian välisestä vuorovaikutuksesta ennemmin kuin suorasta käskytyssuhteesta kommunistisen puolueen taholta. Puolue ei antanut säveltäjille valmiita vastauksia musiikin sosialistiseen realismiin.

Kun Sovetskaja Muzykassa alkoi keskustelu musiikin tilasta, on tärkeää huomata, että käytettiin nimitystä neuvostomusiikki. Myös liittoon kuuluvista säveltäjistä tuli neuvostosäveltäjiä. Jo ensimmäisessä yrityksessä määrittää musiikin sosialistista realismia, Viktor Gorodinski (1933a: 6) käytti neuvostomusiikin käsitettä. Tällä käsitteellä pyrittiin tekemään ero länsimaiseen musiikkiin. Kyseessä ei ollut irtiotto venäläisestä musiikkiperinteestä, päinvastoin, neuvostomusiikin pohja nähtiin tuolloin juuri vanhoissa venäläisissä mestareissa. Lehden päätoimittaja Tsheljapov (1933a: 5) teki keskustelun pohjalta johtopäätöksen, että musiikin historia tulisi arvioida uudelleen. RAPMin aikainen politiikka, joka väheksyi keisarillisen ajan säveltäjiä, oli selvästi ollut virheellinen. Tsheljapov korosti että historiaa tulisi arvioida nykypäivän lähtökohdista käsin. Menneestä tulisi etsiä esikuvia, jotka auttaisivat kehittämään neuvostomusiikkia. Musiikinhistoriaan perehtyminen ei ollut siis itseisarvo sinänsä, vaan sen tuli hyödyttää nykyhetkeä ja tulevaisuutta. (Kaltat \& Rabinovitsh 1933b: 40.)

RAPMin vanhan taiteen vastaisen politiikan murtumisen suorana seurauksena oli venäläisten klassikoiden paluu estradille. Esimerkiksi Bolshoi-teatterin näytännöistä vuosina 1928-41 oopperoista $78 \%$ ja baleteista $55 \%$ oli vanhoja klassikoita, vaikka vuosina 1929-31 monien klassikoiden esitys estettiin. Vallankumouksen jälkeiset 
teokset jäivät selkeästi vähemmistöön isojen teattereiden estradilla. (Sovetskaja kul'tura 1988: 167-168.) Timo Vihavainen (2000: 216-252) on osoittanut, kuinka 1930-luvulla klassismi korvasi kaikissa taiteissa avantgardismin ja modernit kokeilut. Musiikissa tämä näkyi juuri klassikkojen paluussa estradeille, sekä toisaalta säveltäjien klassismiin tähyävässä tyylissä.

Gorodinski (1933b: 2) ehdotti artikkelissaan, että musiikinhistoriasta pitäisi ottaa esille ja analysoida aikanaan sävellettyä realistista musiikkia. Tätä kautta olisi Gorodinskin mukaan mahdollista löytää tukea musiikin sosialistisen realismin kehittämiselle. Tässä korostui näkemys siitä, että menneisyydestä tulisi hakea nimenomaan nykyhetken tarpeita tukevia piirteitä. Modest Musorgskin oopperoita oli jo RAPMin aikana tutkittu. Uuden tulemisen kokivat niin Tshaikovskin, Stravinskin kuin Glinkankin musiikki. Sovetskaja Muzykassa julkaistiin uusia tutkimuksia kunkin säveltäjän teoksista ja urasta, Stravinskin osalta tosin keskityttiin ennen kaikkea vanhempaan tuotantoon. Usein näissä sivuttiin säveltäjien urakehitystä myös marxilaisesta näkökulmasta. Säveltäjistä arvioitiin heidän mahdollista vallankumouksellisuuttaan, sekä suhteitaan talonpoikiin ja työväestöön. (Zhitomirski 1933: 50-65; Groman-Solovtsov 1934: 24-34; Alshvang 1935: 16; ks. myös Kim 1988: 168.) Esimerkiksi Mihail Glinkasta löydettiin yhteyksiä vuoden 1825 dekabristikapinaan sekä Alexander Herzeniin. Glinkan osoitettiin olleen aikanaan yhteiskunnallisesti edistyksellinen hahmo ja näin ideologisesti perusteltavissa esikuvaksi. (Kaltat \& Rabinovitsh 1934: 27-28.)

Proletaarimuusikoiden pyrkimys luoda uusi proletariaatin kulttuuri ilman porvarillista menneisyyttä hylättiin ja tuomittiin virheelliseksi. RAPMin arvioitiin toteuttaneen Leninin näkemyksiä virheellisesti. Lenin oli asettanut kirjoituksissaan porvari- ja proletaarikulttuurin vastakkain ja RAPM oli pyrkinyt toimillaan toteuttamaan tämän käytännössä. Pyrkimys hylätä koko vanha kulttuuri kuitenkin tuomittiin ja todettiin, että uuden kulttuurin rakentamisen tulisi alkaa vanhan pohjalta. (Kaltat \& Rabinovitsh 1933b: 8.) Myös säveltäjä Juri Shaporin (1933: 128) korosti, että RAPMin pyrkimys dogmatisoida Leninin näkemyksiä oli ollut kohtalokas virhe. Shaporin korosti RAPMin erehtyneen myös pakottaessaan kaikki säveltämään joukkolauluja ja marsseja. Tämä sinfonian ja instrumentaalimusiikin väheksyminen esti neuvostomusiikin tasapuolisen kehittymisen.

Proletaarimuusikot olivat pyrkineet korostamaan joukkolauluja osittain siksi, että niiden usein yksinkertaiset tekstit ja melodia oli helppo ymmärtää. Joukkolaulujen esittäminen tapahtui usein suurissa tapahtumissa, jolloin mahdollisimman monet pääsivät osallisiksi näistä teoksista. Ne näyttivätkin toteuttavan ajatuksen siitä, että sosialistinen taide olisi mahdollisimman monen ulottuvilla ja ymmärrettävissä. RAPMin aikana tämä työ oli ennen kaikkea pakollista ja muita sävellysmuotoja väheksyttiin. Uuden säveltäjäliiton aikana tämä työ ei lakannut, vaan se jäi elämään muiden rinnalle. Näitä teoksia voi kuulla vielä nykyäänkin esimerkiksi Puna-armeijan mieskuoron esittäminä. 
Instrumentaalimusiikin paluu toi mukanaan uuteen ideologiaan liittyvän ongelman. Vaikka Stalin sanoi taiteesta virallisesti hyvin vähän, on lause "taiteen tulee olla sosialistista sisällöltään, kansallista ulkoasultaan" jäänyt elämään. Virallisen ideologian mukaan taide saattoi muodoltaan olla vapaata, mutta sen tuli palvella sosialismin rakentamista. (Vihavainen 2000: 234.) Kansallisuuden korostuminen näkyi esimerkiksi kansanlaulujen keräämistyössä ja kansanmusiikin aseman korostumisessa. Sisältökysymys puolestaan oli musiikin osalta varsin ongelmallinen. Jos ajatellaan esimerkiksi oopperaa, on sosialistinen sisältö helppo kuvitella teokseen oikeanlaisen libreton kautta. Sama pätee laulu- ja kuoromusiikissa. Sen sijaan instrumentaalimusiikki asettaa ongelman - millä tavoin esimerkiksi sinfonia voi ilmentää sosialismia?

Säveltäjäliiton toiminnan alkuvuosina ei puhuttu yleensä suoraan sosialistisesta sisällöstä, vaan käytettiin nimitystä neuvostotematiikka. Tällä viitattiin siihen, että teosten aiheet jollain tavalla käsittelivät ajankohtaisia tai keskeisiä asioita ja tapahtumia Neuvostoliitossa. Esimerkiksi Sergei Prokofjev, joka tässä vaiheessa ei vielä ollut pysyvästi emigroitunut Neuvostoliittoon, ilmoitti kirjoituksessaan vilpittömän halunsa säveltää uusi ooppera neuvostotematiikkaan (Prokofjev 1933: 99). Vissarion Shebalin taas kokeili sinfonian ja laulun yhdistämistä säveltämällä sinfoniansa Lenin Majakovskin samannimiseen runoon (Schwarz 1983: 162; Ostretsov 1934a: 4-26). Puhtaan instrumentaalimusiikin osalta yksi ratkaisumalli oli tehdä sinfoniasta ohjelmallinen. Esimerkiksi Miaskovski antoi 12. sinfonialleen aiheeksi kolhoosit (Keldysh 1934: 8) ja otti tätä kautta käsiteltäväksi ajankohtaisen aiheen neuvostotematiikasta.

Monet neuvostoyhteiskunnan ideologiset periaatteet näyttäisivät musiikissa toteutuvan ulkomusiikillisesti. Yksi näistä tekijöistä oli juuri musiikin suuntaaminen uusille kuulijoille. Porvariston sijasta musiikki oli suunnattava nyt uudelle kuulijakunnalle, tavalliselle kansalle. Lisäksi pyrittiin myös nostamaan kansan kulttuurista tasoa. Kun luovuttiin ajatuksesta että proletariaatti loisi omaehtoisesti oman kulttuurinsa, katsottiin, että taiteen ammattilaisten tulisi kasvattaa proletariaattia. Seurauksena oli laajamittainen taidekasvatusprojekti, jossa suuret teatterit ja orkesterit jalkautuivat kolhooseille ja tehtaille. Toisaalta konserttitalojen esityksiin jaettiin ilmaislippuja tehtailla, mm. palkkioina menestyksekkäille työntekijöille. (Esim. Druzhinina 1934: 71.) Bolshoin ja Moskovan filharmonian lisäksi itse säveltäjät olivat mukana tässä työssä suunnaten sävellyksiä nimenomaan harrastelijapiireille. Valtio tuki aktiivisesti tätä harrastustoiminnan kehittämistä. (Esim. Kiselev 1934: 69.) 


\section{Marxilaisuutta musiikissa}

Kaikki eivät kuitenkaan tyytyneet ulkomusiikillisten asioiden korostamiseen. Osa musiikkitieteilijöistä ja säveltäjistä pyrki löytämään vastauksia siihen, onko musiikilla mahdollista ilmentää asioita. Huomattavana tekijänä musiikin kehittämisessä Sovetskaja Muzykassa nousi esille musiikkitieteen rooli. Erityisen ongelmallisena koettiin se, että musiikkikritiikki, musiikkitiede ja käytännön sävellystyö olivat ajautuneet kauaksi toisistaan. Musiikkikritiikki oli "epätieteellistä" ja perustui makukysymyksille. (Ryzhkin 1934: 51.) Teoksia arvosteltiin akselilla "pidän, en pidä". Esille nousikin ajatus siitä, että musiikkikritiikki pitäisi kytkeä osaksi sävellystyön kehittämistä. Tämä vaati kriitikoiden kytkemistä osaksi säveltäjäliiton toimintaa. Yksi kritiikin tasoa arvostelleista säveltäjistä oli Dmitri Shostakovitsh (1933: 120-121), joka valitti että kritiikkejä kirjoittivat useimmiten ammattitaidottomat henkilöt. Musiikkikritiikki laahasi kehityksessä jäljessä, eikä vastannut sävellystyön tarpeita.

Sovetskaja Muzykan myöhempi pääkirjoitus (5/1934: 3) osoitti, että kehitys ei lähtenyt käyntiin kovinkaan nopeasti. Musiikkikritiikki oli kirjoituksen mukaan suorastaan kehnolla tasolla. Musiikkitieteen tulisikin ottaa kritiikki haltuunsa. Myöhemmät kirjoitukset osoittavat, että musiikkikritiikin tason nostaminen tarkoitti käytännössä kritiikin tieteellistämistä ja koulutuksen lisäämistä. Tieteellistämisen periaatteissa taas oli selvä vaatimus marxilaisten metodien löytämisestä kritiikin tueksi. Samaan aikaan säveltäjäliitossa kehitettiin ajatusta teosten ennakkokuulemisesta. Ajatuksena oli lähentää musiikkitiedettä ja sävellystyötä. Musiikkitieteen mahdollisuudet auttaa säveltäjiä liittyivät ennen kaikkea pokazy-käytäntöön, eli teosten ennakkokuulemiseen jo ennen niiden valmistumista. Säveltäjät saattoivat toverillisessa ilmapiirissä käydä esittämässä kollegoilleen otteita valmisteilla olevista teoksista.

Myöhemmin tästä käytännöstä muodostui pahamaineinen ennakkosensuurin väline, kun erityisesti antiformalismikampanjoiden jälkeisessä ilmapiirissä taiteilijoiden työtä ryhdyttiin aktiivisesti ohjailemaan. Alkuvaiheessa ajatus ainakin vaikutti vilpittömältä. Musiikkitieteilijä Kulakovski kuitenkin korosti että ennen kuin musiikkitiede saattoi auttaa säveltäjiä, tulisi tieteen omia rivejä tiivistää. Musiikkitieteilijöiden olisi Kulakovskin (1934: 97) mukaan tullut ensin kerätä kokemuksia käytännön työstä ja tutustua siihen, mitä jo on tehty. Vasta sen jälkeen heistä voisi olla todellista hyötyä säveltäjille. Useissa muissakin kirjoituksissa nousi rivien välistä esille ajatus siitä, että musiikkitieteen tulisi ohjata musiikkirintamaa kokonaisuudessaan. Musiikkitieteen rooli oli huolehtia musiikillisen työn suuntaamisesta. Musiikkitiede ja -kritiikki tulisivat olemaan ratkaisevassa asemassa uuden musiikin etsimisessä ja suuntaamisessa, kuten säveltäjä Krein (1933: 121) kirjoitti jo Sovetskaja Muzykan ensimmäisessä numerossa.

Musiikkitieteen rooli nousi esille päätoimittaja Tsheljapovin (1933a: 3) tehdessä yhteenvetoa lehdessä esitetyistä asioista. Hänen mukaan taiteessa oli kyse joukosta 
menetelmiä, joilla taiteilija ilmaisi omaa taiteellista ideologiaansa. Taiteilija toi teknisten seikkojen, kuten rytmin ja harmonian lisäksi esille omaa ideologiaansa, musiikki oli siis itseilmaisun väline. Musiikkitieteen olisikin kyettävä auttamaan säveltäjää tämän oman ideologian ilmaisussa. Ratkaisevaa tässä ajatuksessa on se, että taide olisi kykenevä ilmaisemaan ideologiaa. Taiteilijan ideologiaa olisi tällöin myös mahdollista ohjata haluttuun suuntaan. Musiikkitieteen tehtäväksi nähtiin suunnata taiteilijoiden ideologiaa neuvostoideologian suuntaan.

Tsheljapov (1933a: 4) katsoi, että taiteilijan luomistyössä vaikuttaa filosofisia, esteettisiä ja tieteellisiä ilmiöitä, joilla on kaikilla vaikutus taiteilijan ilmaisemiin asioihin. Myös taiteilija oli yhteiskunnan tuote ja marxilaisen tulkinnan mukaan tällöin riippuvainen kulloisestakin yhteiskunnan kehitysvaiheesta. Taide ilmaisi Tsheljapovin mukaan taiteilijan ajatuksia ja tunteita. Musiikissa tämä tapahtui melodisin, harmonisin ja instrumentaalisin keinoin. Nämä olivat kuitenkin vain ilmaisukeinoja. Musiikkitieteen tehtävä olikin Tsheljapovin mukaan auttaa nostamaan musiikkitiede tasolle, jolla se kykenisi auttamaan säveltäjiä ymmärtämään oma luokkatietoinen ideologiansa. Tällöin se ideologia, jota säveltäjä taiteessaan ilmentää, saadaan paremmin ilmentämään neuvostoyhteiskuntaa ja sen kehitysvaihetta. Juuri tästä syystä musiikkitieteen ja sävellystyön lähentäminen nähtiin niin tärkeäksi. Musiikkitieteen tuli auttaa säveltäjiä ymmärtämään taiteen luokkasidonnaisuus.

Neuvostomusiikkitieteen alkuaikojen voimahahmo Boris Asafjev, jonka balettia Pariisin liekki (1932) on pidetty ensimmäisenä herooisena neuvostobalettina, esitti samansisältöisen näkemyksen musiikin yhteiskunnallisesta luonteesta. Asafjev (1933: 107) esitti, että säveltäjän tulisi omassa luovassa työssään ammentaa proletariaatin luokkasodasta. Ympäröivä todellisuus tulisi huomoida paremmin luovassakin työssä ja sitä tulisi tarkastella marxilais-leniniläisen kehitysfilosofian avulla. Säveltäjien organisoitumisen perustana oli Asafjevin mielestä musiikin sosiaalisen luonteen tunnustaminen. Musiikki ei ollut vain symboli tai todellisuuden kopio, vaan luonnon voimakas ilmentymä. Musiikki ei siis ollut vain henkilökohtaiseen kokemukseen perustuva taidemuoto, vaan taiteilijan ilmaus yhteiskunnasta, jossa hän eli ja vaikutti. Tämä näkemys tekee mahdolliseksi sen, että voidaan ajatella musiikin sosialistisen realismin olemassaolo. Jos musiikki ei kykenisi ilmentämään todellisuutta tai siinä elävän taiteilijan ideologiaa, ei se pystyisi myöskään hyödyttämään sosialismin rakentamista.

Musiikin yhteiskunnallinen luonne ja kyky ilmentää todellisuutta on se perusteesi, jolle marxilainen musiikkikäsitys Neuvostoliitossa nojasi. Tätä kautta Neuvostoliiton musiikkielämän käytännöistä selviää monta asiaa. Koska säveltäjän oli mahdollista tuoda esille ideologiaa, hän saattoi myös hyödyttää sosialistista yhteiskuntaa. Tätä kautta on ymmärrettävissä myös 1930-luvulla voimakkaasti noussut keskustelu sisällön ja muodon suhteesta, joka jatkui käytännössä koko Neuvostoliiton olemassaolon 
ajan (esim. Schwarz 1983: 277).

Neuvostomusiikin keskeinen ongelma oli muodon ja sisällön vastakkainasettelu. Antiformalismikampanjoiden yhteydessä formalismista syytettiin välillä teoksia, joissa formalismin alkuperäinen merkitys oli jo kadotettu. Kun Sovetskaja Muzykas$s a$ alun perin puhuttiin formalismista, viitattiin sillä siihen, että muoto oli teoksessa syrjäyttänyt sisällön. Formalismissa ei tärkeää ollut enää se mitä ilmaistaan, vaan miten se tehdään. Ideologisesti ajateltuna tämä oli kestämätöntä, koska sisällön tulisi olla ratkaisevassa asemassa. Musiikkitieteestä puhuttaessa kontrapunktin, harmonian ja muoto-opin, kaikkien perinteisten musiikkiteoksen tarkastelutapojen osalta korostettiin sitä, että ne olivat kukin syntyneet palvelemaan historiallisia tarpeita. Ne eivät olleet objektiivisia, vaan empiirisesti syntyneitä, tietyn kehitysvaiheen tuotoksia. Näillä tarkastelutavoilla olikin vain välinearvo ja niiden tuli palvella sisällön tarkastelua. Tiedostamalla musiikin luokkasidonnaisuus, päästäisiin totuudenmukaisempaan arvioon sävellyksestä. Uusi neuvostomusiikki vaati uuden arviointitavan. (Tsheljapov 1933a: 2.)

Toinen neuvostomusiikkitieteen suuri hahmo Roman Gruber (1934: 14) katsoi omassa kirjoituksessaan, että kaikki taide heijasti ympäröivää todellisuutta. Taide ilmaisi luokkansa historiallisen kehitysvaiheen todellisuutta, joten musiikki erosi muista taiteista vain keinojensa puolesta. Myös musiikki oli sidottu historiallisiin kehitysvaiheisiin. Ongelma oli Gruberin mielestä ennen kaikkea ilmaisukeinojen löytämisessä, eikä niinkään kysymyksessä musiikin luonteesta. Gruber vei näkemyksensä esimerkkien avulla varsin syvälle pyrkien osoittamaan, että musiikki meni harmonian avulla pelkkää kuuloaistia huomattavasti syvemmälle. Hänen mielestään musiikki kykeni ilmentämään ideologiaa varsin laajasti. Musiikki ei näin olisi vain esteettinen, luontoon liittyvä ominaisuus, vaan (Gruber lainaa Marxia) "koko maailman historiallisen kehityksen tuote". Musiikki oli tulos ihmisen aktiivisesta luonnon hyödyntämisestä. (Gruber 1934: 15-16.)

Sovetskaja Muzykan teoreettisissa keskusteluissa sivuttiin vuosina 1933-34 koko ajan sosialistista realismia. Sosialistisesta realismista keskusteltiin yhä enemmän lähestyttäessä elokuussa 1934 pidettyä kirjailijakongressia. Formalismista alkoi nopeasti tulla sosialistisen taiteen suora vastakohta. Keskustelulla formalismista taiteessa oli tosin pitkät juuret, musiikkikriitikko Ostretsovin (1934b: 6) mukaan keskustelu alkoi jo 1920-luvun alussa. Olennaista kuitenkin oli, että formalismin ja sosialistisen realismin vastakkainasettelu mahdollisti sosialistisen realismin, edes summittaisen, määrittelyn. 


\section{Musiikin sosialistisen realismin luonne}

Myöhemmin tehdyt tulkinnat sosialistisesta realismista ovat korostaneet varsin toisenlaisia asioita kuin säveltäjäliiton perustamisajan keskustelut. Sheila Fitzpatrick (1992: 216-217) on tehnyt sosialistisesta realismin tulkinnan neuvostoeliitin maun toteuttajana. Hän viittaa siihen eroon, joka oli vallankumouksen aikaisten ideaalien ja 1930-luvun nousseen, stalinistiseksi kutsutun neuvostotaiteen välillä. Siirtymä pikkuporvarilliseen makuun on selkeä. Myös Boris Groysin (1992: 6-9) tulkinta sosialistisesta realismista on samantyylinen. Groysin mukaan sosialistisella realismilla ei ollut mitään tekemistä kansan maun kanssa. Sosialistisen realismin muovasi se taiteellinen eliitti, joka oli omaksunut kokemuksensa jo 1920-luvun avantgardesta. Sosialistinen realismi ei siis heijastanut kansan traditionalistisia makutottumuksia, jotka suuntautuivat ennemminkin Hollywood-komedian ja jazzin suuntaan. Sosialistinen realismi oli hyvin koulutetun ja kokeneen eliitin luoma elämästä ja viihteestä poispäin suuntautunut didaktinen metodi.

Nämä käsitykset ovat ristiriidassa sen tosiasian kanssa, että ainakin aluksi säveltäjiä ja musiikkitieteilijöitä kannustettiin jalkautumaan kansan pariin. Gorodinskin (1933c: 2) mukaan pohja sosialistiselle realismille löytyisi kolhooseilta ja tehtailta. Toisaalta myös Gorodinskin näkemyksessä musiikillinen eliitti määritti uuden musiikin, kansan rooli oli toimia innoittajana, ei aktiivisena toimijana. Myös vanhojen mestariteosten korostaminen uuden tyylin etsimisessä sopii hyvin Groysin tulkintaan. Ylipäätään se, että Sovetskaja Muzykassa käytiin keskustelua neuvostomusiikista, osoittaa määrittelyn olleen musiikillisen eliitin käsissä. Sovetskaja Muzyka oli säveltäjäyhteisön sisäinen lehti, jota säveltäjien lisäksi lukivat korkeintaan puolueen taiteen ja kulttuurin edustajat.

Sosialistisen realismin määrittely tiivistyy kolmeen elementtiin, jotka venäjäksi kuuluvat partijnost', idejnost', narodnost'. Ne voisi suomentaa puoluekantaisuudeksi, ideologiseksi kestävyydeksi ja kansanomaisuudeksi. Käytännössä tämä tarkoitti sitä, että taiteen tuli kuvata asioita kansan näkökulmasta ja pyrkiä heijastamaan sen kokemusmaailmaa. Toisaalta vaadittiin ideologista kestävyyttä ja sisältöä taiteeseen. Näiden ylitse ulotettiin vaatimus puoluekantaisuudesta. Kommunistinen puolue, joka katsoi olevansa proletariaatin ja luokattoman yhteiskunnan etuvartija, teki perimmäisen määrittelyn sille, mikä oli ideologisesti oikein. Pesosen (1998: 176) mukaan tämä määrittely kuului ennen kaikkea Neuvostoliiton taidepoliittiseen keskusteluun, ei taiteen käytäntöön. Tavallisessa taide-elämässä sosialistisesta realismista tuli lopulta ennen kaikkea klisee.

Tutkimuksessa on käynyt niin, että pitkälti kirjallisuuden kautta johdettua sosialistisen realismin käsitettä on pidetty jo 1930-luvun ilmiönä. On oletettu, että viimeistään kirjailijaliiton perustamiskongressin yhteydessä elokuussa 1934 tämä määrittely oli valmis ja sitä ryhdyttiin soveltamaan. Tällöin valitettavasti menetetään aikalaisten 
näkemykset asiasta. Säveltäjäliitolla ei 1930-luvulla ollut yhtenäistä määrittelyä sosialistisesta realismista, eikä sosialistisen realismin mukaisia teoksia kyetty aukottomasti osoittamaan. Sen sijaan Sovetskaja Muzyka nosti esille useita esikuvallisia teoksia, joiden katsottiin olevan varsin edistyksellisiä, mutta vain harva uskalsi nimetä niitä sosialistisen realismin edustajiksi.

Leningradin säveltäjäliiton osaston ensimmäisenä sihteerinä toiminut Iohelson (1934: 16) nosti esille muutamia leningradilaisten säveltäjien teoksia, joissa hänen mielestään oli huomattava idejnost'. Esimerkeiksi hän nosti Shostakovitshin oopperan Mtsenskin kihlakunnan Lady Macbeth sekä Boris Asafjevin baletin Pariisin liekki. Syyksi teosten merkittävyydelle hän katsoi, että ne eivät olleet osoituksia vain ammattitaidosta, vaan myös luovan metodin uusien elementtien kehittämisestä. Iohelsonin mielestä neuvostomusiikki oli todella jonkin uuden kynnyksellä ja säveltäjät tekivät työtä löytääkseen uusia menetelmiä neuvostomusiikin säveltämiseksi.

Moni säveltäjä näyttäisi korostaneen uuden etsimistä vakavissaan. Kun Stalinin terrori ja taiteen vastaiset hyökkäykset alkoivat 1930-luvun puolivälin jälkeen, sekä uudelleen sodan jälkeen, tuli todellisuudesta monelle kaksijakoinen. Selvitäkseen hengissä yhteiskunnan uusista vaatimuksista, moni kehitti itselleen yksityisen minänsä lisäksi myös julkisen puolen. Julkiset puheet eivät enää vastanneet todellisuutta, vaan kuviteltua todellisuutta. Näin kävi osaltaan myös sosialistiselle realismille, josta lopulta tuli kielikuva, virallisten keskustelujen osa, joka vastasi todellisuutta vain vähän, jos ollenkaan. Vielä taideliittojen perustamisvaiheessa tilanne oli kuitenkin toinen, moni säveltäjä ilmaisi Sovetskaja Muzykassa vilpittömäksi tavoitteekseen sosialistisen taiteen.

Viimeinen sosialistiseen realismiin liitetty tekijä, joka nousi esille jo Sovetskaja Muzykan varhaisissa keskusteluissa, oli historiallinen optimismi. Tällä marxilaiseen kehitysajatteluun liittyvällä käsitteellä tarkoitetaan uskoa parempaan, sosialistiseen tulevaisuuteen. Kehitys vei kohti tulevaa sosialistista yhteiskuntaa, jolloin nykyisyyttä tuli tarkastella tulevaisuuden perspektiivistä. Koska tulevaisuus oli valoisa, tuli pessimismistä ja ideologisesta epävarmuudesta vakavia syytöksiä. (Pesonen 1998: 175) Esimerkiksi Gruber (1934: 19) nosti kirjoituksessaan esille sen, että taiteen tehtävä oli tukea sosialistisen yhteiskunnan rakentamista. Yhteiskunnan realistisen kuvaamisen tuli kuitenkin tapahtua konkreettisten dialektisten abstraktioiden kautta. Ei riittänyt, että taide olisi todellisuuden kanssa sopusoinnussa, vaan todellisuuden tulisi olla osa taidetta. Gruber kuitenkin korosti, että tämä tapahtui abstraktilla tasolla, koska musiikki oli käsitteellinen taide. Sosialistisen realismin käsite musiikissa osoittautuikin hyvin moniulotteiseksi. 


\section{Musiikin paikka yhteiskunnassa}

Huolimatta siitä, että musiikki ei alun perin ollut korkealla kommunistien prioriteeteissa ja se jäi alituisesti kirjallisuuden varjoon, oli sillä oma merkityksensä 1930-luvun yhteiskunnassa. Säveltäjäyhteisö otettiin taiteilijoina mukaan uuteen eliittiin. Olot järjestettiin huomattavasti tavallisten kansalaisten oloja paremmiksi. Samalla tämä eliitin asema kuitenkin tarkoitti uudenlaisia uhrauksia. Taideliiton jäsenyyden kautta taiteilija samalla uhrasi osan taiteellisesta vapaudestaan. Taiteilija suostui, tietoisesti tai tiedostamattaan siihen, että hän tuki neuvostoideologiaa. Stalinin yhteiskunnassa tämä tarkoitti sitä, että taiteilijoista tuli virallisesti yksi Stalinin valtion tukipylväistä. Stalinin jälkeisessä Neuvostoliitossa taiteilijat virallisesti tukivat Neuvostoliittoa. Taideliittojen myötä taiteet valtiollistettiin.

Musiikin valtiollistaminen ja taiteellisen vapauden osittain uhraaminen ei tarkoittanut musiikin kuolemaa. Neuvostoliitto oli kykenevä tuottamaan Shostakovitshin, Schnittken, Shtshedrinin ja Hatshaturjanin kaltaisia säveltäjiä. Erityisesti klassisen musiikin esittäjien ja pedagogien osalta Neuvostoliitto oli erinomaisen tuottelias. Taiteista tuli myös merkittävä osa yhteiskuntaa ja kasvatusjärjestelmää, taidekasvatus oli varsin laajamittaista.

Taideliittojen perustamisen yhteydessä säveltäjäyhteisö kävi laajasti keskustelua säveltäjäliiton toiminnan kohdistamisesta ja suuntaamisesta. Monilla säveltäjillä oli vielä vahva usko siihen, että musiikki oli jonkin uuden kynnyksellä, että uusi neuvostomusiikki oli todella syntymässä. Uuden neuvostomusiikin eräs merkittävä ominaisuus oli yhteiskunnallisuus. Musiikilla olisi tehtävä: yhteiskunnallisen kehityksen tukeminen. Käytännössä tämä näkyi teosten aiheiden valinnassa, mutta myös käyttömusiikin osalta erilaisten joukkotilaisuuksien yhteydessä. Myös aktiivinen toiminta kansan parissa oli tämän periaatteen seurausta. Säveltäjät ja muusikot osallistuivat aktiivisesti harrastelijatoiminnan kehittämiseen. Myös suuret konserttitalot tarjosivat kansalle mahdollisuuden tutustua korkeakulttuurin hedelmiin.

Pohdittaessa käytyä keskusteltua taiteen uusista tehtävistä, täytyy ymmärtää taiteen uudenlainen funktio. Taide ei neuvostoyhteiskunnassa voinut olla individualistinen ilmiö. Taiteilija ei tehnyt taidetta itseään, vaan yhteiskuntaa varten. Musiikkitieteilijä Georgi Hubovin (1934: 7) korostus siitä, että säveltäjän tulisi hylätä individualismi, mutta säilyttää yksilöllinen ote taiteeseen, on varsin kuvaava. Taiteen tulisi siis olla sellaista, että mahdollisimman laajat joukot pääsisivät siihen mukaan ja ymmärtäisivät sitä. Kansan tarpeet olivat virallisesti etusijalla, eivät säveltäjän. Syyt tehdä taidetta olivat Hubovin mielestä täysin erilaiset.

Perinteisiin länsimaisiin yhteiskuntiin verrattaessa taiteen tekemisen ainakin osittain erilaiset syyt aiheuttavat ongelmia arvioitaessa aikakauden neuvostomusiikkia. Nykypäivän näkökulmasta katsottuna osa neuvostoajan sävellyksistä voi vaikuttaa takapajuisilta ja jopa vulgaareilta. Vasta aikakauden parempi ymmärtäminen saattaa 
avata teoksista aivan uusia ulottuvuuksia. Kohderyhmän ja teoksen sisällön vuoksi on mahdollisesti tehty uhrauksia melodiassa, harmoniassa ja rytmiikassa. Tämä on tehnyt nykypäivän näkökulmasta monesta teoksesta pejoratiivisessa mielessä käyttömusiikkia. Omana aikanaan ne eivät sitä välttämättä olleet.

Musiikin rooli oli kuitenkin osaltaan myös kaksijakoinen. Taiteen kasvatuksellinen ja yhteiskunnallinen tehtävä oli toinen puoli uudesta musiikista. Neuvostoyhteiskuntaan 1930-luvun aikana muodostunut uusi eliitti, johon kuuluivat ennen kaikkea puolueen ja armeijan johtoasemissa olevat henkilöt, mutta myös taiteellisten ja tieteellisten organisaatioiden edustajat. Tämän uuden eliitin maulla oli tärkeä rooli sosialistisen realismin muokkaajana. Kun taiteella pyrittiin toisaalta palvelemaan suuria joukkoja, neuvostokulttuuria suuressa mittakaavassa, niin toinen selkeä kohderyhmä oli uusi eliitti. Tässä mielessä taiteen kohderyhmä oli hyvin samantyyppinen kuin länsimaissa, tai 1800-luvun yhteiskunnassa. Korkeakulttuuria kulutti ennen kaikkea kapea eliitti, joskin myös korkakulttuurin kuluttajien pohjaa laajennettiin 1930-luvulla voimakkaasti.

Virallisessa retoriikassa tästä uudesta eliitistä tai sen tarpeista ei luonnollisestikaan puhuttu, vaan näkyvissä oli ainoastaan toinen puoli, kansan tarpeet. Musiikkirintamalla ideologia kohdattiinkin ennen kaikkea yhteiskunnan palvelemisena. Sosialistisen yhteiskunnan tarpeet korostuivat taiteen tehtävistä puhuttaessa. Koska säveltäjäliiton alkuvaiheessa ideologian soveltamisesta musiikissa ei vielä ollut yhtenäistä näkemystä, esille nousi lukuisia vaihtoehtoisia malleja. Myöhemmin ideologia samaistettiin ennen kaikkea monoliittiseen sosialistisen realismin käsitteeseen, jolloin siitä tuli ennen kaikkea virallisen retoriikan klisee. Alkuvaiheen puheet marxilais-leniniläisestä musiikkitieteestä ja uudesta musiikista haipuivat Stalinin terrorin ja antiformalismikampanjoiden myötä.

Politiikan ja musiikin suhde ilmeni taiteen valtiollistumisen kautta. Toisaalta valtiolliset taideliitot tekivät taiteilijoista pysyvästi Neuvostoliiton eliittiä. Toisaalta puolueen ja valtion sulautuessa Stalinin toimien myötä puolue pystyi puuttumaan halutessaan suoraan taideasioihin. Musiikin onneksi säveltäjäliiton lopullinen perustaminen lykkääntyi aina vuoteen 1948. Vuoden 1936 antiformalismikampanjaa lukuun ottamatta säveltäjät selvisivät varsin vähillä vaurioilla. Vaikka voimakkain hyökkäys kohdistettiin Shostakovitshiin, ei häntä lopulta edes pidätetty, vaan hän säilytti asemansa johtavana säveltäjänä Neuvostoliitossa. Säveltäjien poliittinen kytkeminen jäi vajavaiseksi osittain siksi, että säveltäjissä oli varsin vähän puolueen jäseniä, osittain siksi, että puolueen huomio meni pitkälti kirjallisuuteen. Säveltäjät hyötyivät tilanteesta saaden taideliiton tarjoamat materiaaliset edut, mutta kärsien poliittisesta painostuksesta vain vähän.

Kysymys säveltäjien omista ambitioista vasta perustetun säveltäjäliiton suhteen on selvittämisen arvoinen ${ }^{4}$. Säveltäjien omissa mielipiteissä näkyi selkeästi se, et- 
tei Stalinin todellisia pyrkimyksiä tunnettu. Puolue ja neuvostovaltio nähtiin vielä osittain ihanteellisessa valossa. Moni säveltäjä pyrki aidolla tavalla palvelemaan yhteiskunnallisia pyrkimyksiä ottamalla huomioon tavallisen kansan lähtökohdat ja tarpeet. Säveltäjien keskustelun ja näkemysten tarkastelu onkin ensiarvoisen tärkeää, jos aikakauden musiikkia ja taiteellisia lähtökohtia halutaan ymmärtää. Tuntematta aikakauden luonnetta myös musiikin arvioiminen jää vajavaiseksi ja pinnalliseksi.

\section{Viitteet}

${ }^{1}$ Käytän tekstissä suoran translitteroinnin sijasta venäläisten nimien vakiintuneita muotoja. Eli Stravinskij on Stravinski, Prokof'ev on Prokofjev, Bol'shoj-teatteri on Bolshoi. Myös nimien $i j$-pääte typistyy $i$ :ksi.

${ }_{3}^{2}$ Nelsonilta on julkaistu samasta teemasta laajempi teos kesällä 2004.

${ }_{4}^{3}$ Kysymykseen säveltäjäliittojen olemassaolosta paneudun tarkemmin väitöskirjassani.

${ }^{4}$ Paneudun tähän tarkemmin väitöskirjatutkimuksessani.

\section{Lähteet}

Alkuperäislähteet - Sovetskaja Muzyka

Alshvang, A. (1935) "Filosofskie motivy v tvortshestve Skrjabina". SovMuz 7-8/35.

Asafjev, B. (1933) "Istoritsheskij god". SovMuz 3/33.

Druzhinina, E. (1934) "Kak Mosfil obsluzhivaet rabotshego slushatelja". SovMuz 7/34.

Ginzburg, S. (1934) 'Na putjah konkretnoj muzykal'noj kritiki”. SovMuz 6/34.

Gorodinski, V. (1933a) "K voprosu o sotshialistitsheskom realizme v muzyke". SovMuz 1/33.

Gorodinski, V. (1933b) "Problema soderzhanija i obraznosti v muzike”. SovMuz 5/33.

Gorodinski, V. (1933c) "Vypolnim nash dolg pered kolhozami". SovMuz 6/33.

Groman-Solovtsov, A. (1934) "Neskol'ko myslej o Tshaikovskom". SovMuz 2/34.

Groman-Solovtsov, A \& Ryzhkin, I. (1933) "Muzykal'noe radioveshtshanie za god”. SovMuz 4/33.

Gruber, R. (1934) "O realizme v muzyke". SovMuz 6/34.

Hubov, Georgi (1934) "Za massovuju pesnju, za massovuju simfoniju!" SovMuz 2/34.

Iohelson, V. 1934. "Leningradskij Sojuz sovetskih kompozitorov k XVII s'ezdu partii”. SovMuz 1/34.

Kaltat, L. \& Rabinovitsh, D. (1933a) "Na dva fronta! Dejatel'nost' b. RAPM i voprosy sovetskogo muzykal'nogo tvortshestva". SovMuz 2/33.

Kaltat, L. \& Rabinovitsh, D. (1933b) "V bojah za nasledtsvo". SovMuz 3/33.

Kaltat, L. \& Rabinovitsh, D. (1934) "U istokov russkoj natsional'noj muzykal'noj shkoly”. SovMuz 3/34.

Keldysh, Ju. (1934) "12-ja simfonija Mjaskovskogo i nekotorye problemy sovetskogo simfonizma". SovMuz 2/34.

Kiselev, M. (1934) "Itogi okryzhnoj olimpiady kasnoarmejskoj hudozhestvennoj samodejatel'nosti MVO”. SovMuz $3 / 34$.

Krein, Aleksander (1933) "Kompozitor i kritika". SovMuz 1/33.

Kulakovski, L. (1934) "Pis'mo v redaktsiju. Ob organizatsii otdela 'Tvortsheskaja laboratorija muzykovedenija'". SovMuz 3/34.

Ostretsov (1934a)"'Lenin' Simfonija V. Shebalina". SovMuz 3/34.

Ostretsov, A. (1934b) "Protiv formalizma v muzyke. (O tvortshestve G. Litinskogo)". SovMuz 4/34.

Pashtshenko, A. (1933) "Protiv gruppovshtshiny". SovMuz 3/33.

Prokofjev, S. (1933) "Zametki". SovMuz 3/33.

Rimski-Korsakov, A. (1933) "Muzykal'no-istoritsheskaja perspektiva projasnjaetsa". SovMuz 3/33.

Ryzhkin, N. (1934) "O muzykovedtsheskoj rabote Sojuza sovetskih kompozitorov". SovMuz 2/34.

Shaporin, Ju. (1933) "Moi mysli o godovshtshine 23 aprelja". SovMuz 3/33.

Shostakovitsh, D. (1933) "Sovetskaja muzykal'naja kritika otstaet". SovMuz 3/33.

Sovetskaja Muzyka (1933) "SSK. Tvortsheskaja i organizatsionnaja dejatel'nost'. O material'no-bytovom polozhenii kompozitorov (iz materialov k plenumu SSK)". SovMuz 4/33.

Sovetskaja Muzyka (1934a) "Smotr hudozhestvennoj samodejatel'nosti v kolhozah". SovMuz 3/34.

Sovetskaja Muzyka (1934b) "Za vysokoe katshestvo sovetskoj muzykal'noj kritiki (k itogam sessii muzykal'noj kritiki v Moskve (7-10 aprelja 1934 g.))". SovMuz 5/34)

Tsheljapov, N. (1933a) "Marksistsko-leninskoe muzykovedenie na novuju stupen’!” SovMuz 4/33. 
Tsheljapov, N. (1933b) "O zadatshah zhurnala 'Sovetskaja Muzyka'”. SovMuz 1/33.

Zhitomirski, D. (1933) "O simfonizme Tshaikovskogo". SovMuz 6/33.

\section{Muut alkuperäislähteet}

"'O perestrojke literaturno-hudozhestvennyh organizatsij. Postanovlenie TsK VKP(b) 23.4.1932." KPSS o kul'ture, prosveshtshenii i nauke 1963, 213-214. Moskva: Sbornik dokumentov.

Pravda 28.1.1936 "Sumbur vmesto muzyki. Ob opere 'Ledi Makbet Mtsenskogo uezda'."

Pravda 6.2.1936 "Baletnaja Falsh (balet 'Svetlyj rutshej', libretto F. Lopyhova i Piotrovskogo, Muzyka D. Shostakovitsha. Postanovka Bol'shogo teatra)."

Stetsky, A. I. (1977) "Under the Flag of the Soviets, Under the Flag of Socialism”. Soviet Writers' Congress 1934. The Debate on Socialist Realism and Modernism in the Soviet Union. Ed. H. G. Scott. London.

\section{Tutkimuskirjallisuus:}

Brooke, Caroline (2001) "Soviet Music in the International Arena, 1932-1941". European History Quarterly $31(2) / 2001$.

David-Fox, Michael (1999) "What Is Cultural Revolution?" The Russian Review 58(April)/1999.

Fitzpatrick, Sheila (1992) The Cultural Front: The Power and Culture in Revolutionary Russia. Ithaca: Cornell University Press.

Garrard, John; Garrard Carol (1990) Inside the Soviet Writers' Union. New York: The Free Press.

Groys, Boris (1992) The Total Art of Stalinism. Avant-Garde, Aesthetic Dictatorship, And Beyond. Kääntänyt saksankielestä Charles Rougle. Princeton: Princeton University Press.

Herrala, Meri (2003) "Vano Muradelin ooppera 'Suuri ystävyys' ajallisissa, ideologisissa ja organisatorisissa yhteyksissään”. Ajankohta. Poliittisen historian vuosikirja 2003. Toim. Klaus Lindgren. Helsingin ja Turun yliopistot.

Hingley, Ronald (1979) Russian Writers and Soviet Society 1917-1978. London : Weidenfeld \& Nicolson.

Jakovlev, M. M. (1981) "Sojuz Kompozitorov SSSR.” Muzykal'naja Enciklopedija. Osa 5. Red. Keldyš, Ju. V. Moskva: Sovetskaja Enciklopedija.

Kenez, Peter (1989) "Lenin's concept of culture". History of European Ideas 11/1989.

Kenez, Peter (1999) A History of the Soviet Union from the Beginning to the End. Cambridge: Cambridge University Press.

Kim, M. P. (red.) (1988) Sovetskaja kul'tura v rekonstruktivnyj period 1928-1941. Akademija nauk SSSR, Institut Istorii SSSR. Moskva: Nauka.

Korzhihina, T. P. (1990) "Obshtshestvennie organizatsii v polititsheskoj sisteme strany. Iz istorii dobrovol'nyh obshtshestv v pervoe desjatiletie Sovetskoj vlasti." Istorija SSSR 5/1990.

Krebs, Stanley (1970) Soviet Composers and the Development of Soviet Music. London: George Allen \& Unwin.

Maksimenkov, Leonid (1993) "'Partija - nash rulevoj'”. Muzykal'naja zhizn' nro 15-16/1993.

Maksimenkov, Leonid (1997) Sumbur vmesto muzyki. Stalinskaja kulturnaja revoljutsija 1936-1938. Moskva: Juriditšeskaja kniga.

McCauley, Martin (1981) The Soviet Union since 1917. London: Longman.

Mikkonen, Simo (2002) Neuvostosäveltäjän muutoksen tie. Shostakovitshin sävellystyyli ja sen muutos neljännestä viidenteen sinfoniaan. Julkaisematon Pro Gradu -tutkielma. Jyväskylän yliopisto.

Nelson, Amy (2000) "The Struggle for Proletarian Music: RAPM and the Cultural Revolution". Slavic Review 59(1)/2000.

Perris, Arnold (1985) Music as Propaganda. Art to Persuade, Art to Control. Westport: Greenwood Press.

Pesonen, Pekka (1998) Venäjän kulttuurihistoria. Helsinki: Helsingin yliopiston Lahden tutkimus- ja koulutuskeskus.

Schwarz, Boris (1983) Music and Musical Life in Soviet Russia. Enlarged edition, 1917-1981. Bloomington: Indiana university press.

Taruskin, Richard (1997) Defining Russia Musically. Historical and Hermeneutical Essays. Princeton: Princeton University Press.

Tucker, Robert C. (1998) "Stalinism and Stalin. Sources and Outcomes". Stalinismus vor dem Zweiten Weltkrieg. Neue Wege der Forschung. Hrsg. Manfred von Hildermeier \& Elisabeth Müller-Luckner. München: Oldenbourg Verlag.

Vihavainen, Timo (2000), Stalinistinen klassismi”. Kivettyneet ihanteet? Klassismin nousu maailmansotien välisessä Euroopassa. Toim. Marja Härmänmaa \& Timo Vihavainen. Jyväskylä: Atena.

Volkogonov, Dmitri (1999/1988) Stalin: Triumph and tragedy. Venäjästä kääntänyt Harold Shukman. London: Weidenfeld \& Nicolson. 